\title{
Article \\ Community Capacity-Building Mobilization towards Energy Transitions in the Era of Thailand 4.0: A Case Study on Biomass Power Plants
}

\author{
Yuttana Homket, Pongthep Sutheravut and Sawpheeyah Nima * \\ Public Policy Institute, Prince of Songkla University, Hat Yai, Songkhla 90110, Thailand; \\ hom_yuttana@hotmail.com (Y.H.); pongthep.s@psu.ac.th (P.S.) \\ * Correspondence: sawpheeyah.n@psu.ac.th; Tel.: +66-814-796-937
}

Citation: Homket, Y.; Sutheravut, P. Nima, S. Community

Capacity-Building Mobilization towards Energy Transitions in the Era of Thailand 4.0: A Case Study on Biomass Power Plants. Energies 2021, 14, 5219. https://doi.org/10.3390/ en14175219

Academic Editor: Adam Smoliński

Received: 9 July 2021

Accepted: 16 August 2021

Published: 24 August 2021

Publisher's Note: MDPI stays neutral with regard to jurisdictional claims in published maps and institutional affiliations.

Copyright: (c) 2021 by the authors. Licensee MDPI, Basel, Switzerland. This article is an open access article distributed under the terms and conditions of the Creative Commons Attribution (CC BY) license (https:// creativecommons.org/licenses/by/ $4.0 /)$.

\begin{abstract}
In 2015, the National Energy Policy Council (NEPC) approved the latest Alternative Energy Development Plan (AEDP) 2015-2036, targeting electricity generation from biomass, biogas, and municipal solid waste by 2036 towards the Thailand 4.0 policy. The small biomass power plants are intensively promoted, contributing to many more public concerns. Therefore, this study provided new insight using the readiness and resilience in the communities near the biomass power plant generation in Southern Thailand. The community readiness model (CRM) and community health impact assessment (CHIA) were adopted using mixed methods during January-November 2019. A total of 999 respondents replied to the questionnaires, 153 informants were interviewed, and the panel was discussed and analyzed by descriptive statistics and content analysis. Findings illustrated that all stakeholder sectors strengthened community-driven development based on the average community readiness $(3.01 \pm 0.11)$ in a vague awareness stage, only with participation in information giving $(75.38 \%)$ and having an impact pain point score of $7.64 \pm 0.54$, which was a highly intense level used to develop the public policy towards biomass power plants. Recent advanced community tools offered new insights for the first time about community strategic plans for sustainable biomass power generation, to achieve community security and values of democracy in Southern Thailand.
\end{abstract}

Keywords: biomass power plant; community mobilization; renewable energy; public policy; Thailand 4.0

\section{Introduction}

Since 2011, the Kingdom of Thailand had stepped up from a lower middle-income economy to an upper-income category country. Currently, the Thai royal government is trying to move from this economic trapping to the high income range status. Consequently, Thailand 4.0, a national strategy driving beyond the limit, has been developed for the new economic model. It started from Thailand 1.0 to 3.0., which were agricultural, light industry, and heavy industry, towards an innovation-based economy or value addition. After the Thailand 4.0 initiative emerged in 2016, this has challenged all sectors towards a value added-driven economic country [1] by transforming to eco-efficiency [2], a healthy and wealthy society [3], raising human security, and protecting the environment [4]. Not only the industry but also renewable energy is a key priority for innovation in this era. Currently, the Thai total energy consumption rapidly increased between 2000 and 2013, slowed down from 2013 to 2019, and dropped by 8\% in 2020 due to lockdown measures and transport restrictions. Since 2016, crude oil production has been slightly decreased ( $-4 \%$ /year) in Thailand. Currently, there are 69.9 million Thai population, 51.3\% energy independence, and $3.69 \mathrm{tCO}_{2}$ / capita $\mathrm{CO}_{2}$ emissions in 2020. However, energy diversification is a priority to ensure enough supply within the country. Energy has a critical role in economic development [5]; it is, therefore, the priority to move beyond the economic traps to become the bioenergy hub in the Southeast Asia region. The national energy policy council has also approved the power development plan (PDP 2018-2037)_renewable energy power generation since 2019, consisting of solar, biomass, hydropower, wind, solid waste, and biogas in 
15.5 GW, 4.7 GW, 3.1 GW, 3 GW, and 1.8 GW, respectively. After launching the renewable energy policy, the domestic and foreign investments have dramatically increased, resulting in circular economic performance and a strong potential to serve regional markets. As energy transition is a key priority, this model also promotes renewable energy policy by shifting from fossil fuels to depleted oil and gas reserves, towards green energy efficient sources and strengthening long-term greenhouse gas emission reduction in 2050 [6]. This is also known as Thailand's low carbon society (LCS) initiative, emerging to reduce carbon dioxide $\left(\mathrm{CO}_{2}\right)$ emissions in the country [7]. The AEDP has increasingly driven alternative energy usage and energy import reduction, such as solar, wind, hydro, waste, biomass, and biogas power. Due to domestic energy consumption rising sharply in the last decade, Thai AEDP 2015-2036 has systematically planned to promote renewable energy power generation [8], including biomass power plants, from $2452 \mathrm{MW}$ in 2014 to $5570 \mathrm{MW}$ in 2036, including Southern Thailand [9].

A biomass power plant is recognized as renewable energy derived from organic materials, such as plants, animals, and waste residues. When those materials are burned, the energy is released as heat and distributes carbon-neutral electricity. It has also claimed to have the potential to reduce greenhouse gas emissions greatly, depending on electricity generation sizes. The community biomass power plant project is usually a VSPP-an extremely small power plant biomass $(<10 \mathrm{MW})$ called a small-scale biomass power plant, located in a community. It has been confirmed to reduce environmental impacts [10] due to its $\mathrm{CO}_{2}, \mathrm{CO}$, and soot emission being less than the larger ones [11]. In Thailand's electrical energy market, private sector participation has also been allowed under the Independent Power Producer (IPP) scheme, such as a minimal power producer (VSPP) biomass power plant that produces no more than $10 \mathrm{MW}$ of electrical power. In contrast, this energy transition is a dilemma between energy security, affordability, sustainability, and other securities, such as food, environment, health, and human security, due to its drawback impacts, including hazardous air pollutants [12], climate change [13], and public acceptance [14]. Moreover, a life cycle approach reported sustainable bioenergy from residual biomass, depending on site allocation [15] and feedstock type [16].

In Southern Thailand, biomass power plant expansion is well interested in domestic and foreign investment due to increasing demand, abundant agricultural waste resourcespara rubberwood-based [17] — and attractive incentives, such as loans at concessionary rates, reduced tax rates, including subsidized infrastructure, or fundamental services. A community biomass power plant project has also been designed to bring about extraneous household income for residents nearby through agricultural-based material selling and sustainable energy. On the other hand, public opposition has gradually emerged due to its health risk impacts, both in residential and occupational settings at the same time. Public perception, acceptance, and engagement towards biomass power generation have been globally emphasized critical roles in influencing sustainable energy security $[18,19]$. Moreover, community mobilization and capacity building based on community-driven development (CDD) have long been recognized for empowering government, private sectors, civil society, and community networks in Thailand [20]. Particularly, community participation in the decision-making process is also well described elsewhere [21-23].

For decades, the community approach tools, particularly the community readiness model (CRM) and community health impact assessment (CHIA), have long been introduced to community members in order to gain insights and understanding in dealing with challenging projects. Briefly, a five-dimension CRM is a crucial strategic tool to build readiness, a coalition [24], resilience, and recovery in community efforts to respond to both threatening issues and to opportunities [25]. It consists of six dimensions, and each dimension can be categorized into nine levels that are well-described elsewhere [26], while CHIA has a critical role in contributing to the strong commitment to public policy [27], based on various community stakeholder engagements in the decision-making step through pain point analysis, strategic management plan, implementation, monitoring, and evaluation in all policy implementation [28]. CHIA is the most significant instrument 
for the community to promote their learning and responsibility for health equity through health-determinant understanding. Since the advent of healthier and wealthier societies, people's pleasurable earnings and well-being in Southern Thailand have been considered part of people's security, including food, environmental, and human security. To become important contributors to the essential energy transition, communities need to obtain three things: community capacity-building transformation, positive community mobilization changes, and community basic needs relying on those securities.

To date, the engagement of the community towards renewable energy policy has not been adequately strengthened, and there has been limited study for those health equity tools in Thailand. Therefore, this study focused on exploring CDD with the specific community approaches of CRM and CHIA, both before and during the small-scale biomass power plant generation which affects the lives of those in the community, with a proper control in the era of Thailand 4.0.

\section{Materials and Methods}

\subsection{Conceptual Framework}

The conceptual framework for community capacity-building mobilization towards energy transitions in the era of Thailand 4.0 focused on (1) critical processes using CRM and CHIA (readiness assessment and collaborative mobilization plan), (2) community capacity-building transformation in 2 periods: before and during biomass power generation (targeted collective action and responsibility), (3) main outcomes (public policy for community efforts and changes), and (4) long distant outcomes (food, environmental, human, and health security). This framework indicates the critical role of social tools for promoting community health and sustainability, as presented in Figure 1.

\section{Community Approaches:}

1. CRM: Preparation

- Readiness level

- Engagement level

- Pain point score

2. CHIA: Mobilization

- Strategic management plan

- Implementation

- Monitoring, and Evaluation

\begin{tabular}{|c|c|}
\hline $\begin{array}{l}\text { Community Capacity- } \\
\text { Building Transformation } \\
\text { 1. Before Investment } \\
\text { - Baseline data } \\
\text { - Decision-making } \\
\text { - Participation } \\
\text { 2. During Power Generation } \\
\text { - Monitoring } \\
\text { - Evaluation }\end{array}$ & $\begin{array}{l}\text { Secuirty Public } \\
\text { Policy: } \\
\begin{aligned} \text { - } & \text { Food } \\
\text { - } & \text { Environment } \\
\text { - } & \text { Human } \\
\text { - } & \text { Health }\end{aligned}\end{array}$ \\
\hline
\end{tabular}

Figure 1. A Framework for community mobilization to promote public policy.

(1) CRM serves the fundamental status of the community, such as readiness, engagement, and impact-related pain point levels.

(2) CHIA explores how to mobilize and strengthen community capacity in learning and resilience towards challenges. It consists of 3 steps: plan, action, and evaluation.

(3) Public Policy (PP) results from both CRM and CHIA processes to provide the ultimate goal(s) and the means to achieve them. 


\subsection{Study Design}

The mixed methods approach was carried out, relying on a quantitative and qualitative study, including a special case study to illustrate the community capacity-building mobilization towards energy transitions in the era of Thailand 4.0 on biomass power plant generation from January to November 2019.

\subsection{Study Participants and Informants}

The respondents and informants aged 20 years and over were community stakeholders, individuals, and organizations that experienced or lived near Southern Thailand's biomass power plants. All 1200 interested parties were invited to participate as stakeholders with purposive sampling. They responded affirmatively to joining this study, equal to 1152 persons.

\subsection{Research Instruments and Data Collection}

\subsubsection{Quantitative Study}

The main research instrument was questionnaires, composing both dichotomous (yes or no) and rating scales for measuring the community readiness, engagement, and pain points scores related to the community biomass power generation. The questionnaires were administered to a total of 1200 residents, health professionals, public service workers, and community leaders, and 999 responses were received (83.25\% response rate). First, the respondents were asked how much they could score for their readiness to respond to the community biomass power plants in 6 dimensions. The score was ranged on a scale of $1-10$, with 1 being the minimum and 10 being the maximum. Second, they were asked whether they had community participation experience in biomass power generation projects at least once a year (yes or no) in seven levels of community engagement. Finally, the researchers investigated the pain point score by measuring their concerns about the current problems and the unintended consequences of the community biomass power generation. The self-reported scores were ranged on a scale of $0-10$, with 0 being the minimum and 10 being the maximum.

\subsubsection{Qualitative Study}

The research tools consisted of interviews, and panel discussions. The participants proposed plans for development through open-ended questions, using CHIA steps with face-to-face interviews and panel discussions to provide a detailed public policy based on a specific problem related to biomass power generation that residents or stakeholders were experiencing. First, 84 community members were invited through the face-to-face interview sessions to explore and gather data for their beliefs, understandings, perceptions, and experiences on the direct and indirect impacts of the VSPP biomass in their communities. Second, the 69 experts and key informants were divided into 3 groups to brainstorm specific strategies to prevent and solve community biomass power plant projects. Third, a total of 153 participants engaged in the panel discussion meeting to extract the current problems, expected problems, and solutions together once again. This step also supported the community decision-making process providing a critical bottom-up public policy. A tape recorder was used, transcribed, and finally deleted after the study finished. Data from different sources were triangulated and validated among research instruments, researchers, and informants to ensure accurate meaning.

\subsection{Analysis and Ethics Consideration}

Quantitative data were analyzed using descriptive statistics, and qualitative data were analyzed using content analysis. For ethics consideration, the Human Ethics Committee, Public Policy Institute, Prince of Songkla University, Thailand, had approved the research proposal before the study was conducted (Ref. No. 19/2559). Researchers had also provided a study information sheet to each participant and details of ethics approval before they obtained written informed consent. 


\section{Results}

This study described the process and the methods of using comprehensive community tools, and both CRM and CHIA processes for the capacity-building mobilization towards energy transitions in the era of Thailand 4.0 in Southern Thailand.

\subsection{Background Characteristics of Respondents}

The demographic characteristics of survey respondents and the percent distribution between sex, age groups, education, and stakeholders are presented in Table 1. Briefly, detailed sociodemographic data revealed that the respondents were predominantly welleducated. The gender, age range, and distribution were equally typical for those respondents. Regarding stakeholder type, $48.85 \%$ of the respondents were from civil society or NGOs, while $33.23 \%$ were village representatives.

Table 1. Characteristics of respondents $(\mathrm{N}=999)$.

\begin{tabular}{|c|c|c|}
\hline Demographic Data & Number & Percentage \\
\hline \multicolumn{3}{|l|}{ Sex } \\
\hline Male & 488 & 48.85 \\
\hline Female & 510 & 51.05 \\
\hline \multicolumn{3}{|l|}{ Age range (years) } \\
\hline $20-40$ & 495 & 49.55 \\
\hline $41-60$ & 504 & 50.45 \\
\hline \multicolumn{3}{|l|}{ Education } \\
\hline High School & 133 & 13.31 \\
\hline Diploma & 436 & 43.64 \\
\hline Higher & 430 & 43.04 \\
\hline \multicolumn{3}{|l|}{ Stakeholder Type } \\
\hline Residents & 231 & 23.12 \\
\hline Health providers & 89 & 8.91 \\
\hline Lawyer/Consultants & 15 & 1.50 \\
\hline Village representatives & 332 & 33.23 \\
\hline Academic institutes & 44 & 4.40 \\
\hline News reporters & 29 & 2.90 \\
\hline Small businesses & 58 & 5.81 \\
\hline Civil society/NGOs & 488 & 48.85 \\
\hline
\end{tabular}

\subsection{Community Preparation Estimation}

The respondents estimated their present readiness, engagement, and pain point experiences towards the community biomass power plants. First, the researchers conducted a community readiness assessment by asking the level of their efforts of action towards the communities' biomass power plants. This readiness score was categorized into six dimensions, with each dimension consisting of nine levels, ranging from none to a high level of belonging, as presented in Table 2. 
Table 2. Community readiness level in 6 dimensions $(\mathrm{N}=999)$.

\begin{tabular}{ccc}
\hline CRM Dimension & Level (Mean \pm S.D) & Readiness Stage \\
\hline Knowledge & $1.24 \pm 0.05$ & No Awareness \\
Efforts & $2.26 \pm 0.09$ & Denial/Resistance \\
Knowledge of Efforts & $3.35 \pm 0.13$ & Vague Awareness \\
Leadership & $3.09 \pm 0.16$ & Vague Awareness \\
Climate & $4.01 \pm 0.16$ & Preplanning \\
Resources & $4.08 \pm 0.09$ & Preplanning \\
Overall Readiness Score & $3.01 \pm 0.11$ & Vague Awareness
\end{tabular}

Scores reported were on a scale of 1-10, with 1 being the minimum and 10 being the maximum. Cut-off score: 1-1.99 = No Awareness; $2.00-2.99$ = Denial/Resistance; 3.00-3.99 = Vague Awareness; $4.00-4.99$ = Preplanning; 5.00-5.99 = Preparation; 6.00-6.99 = Initiation; 7.00-7.99 = Stabilization; 8.00-8.99 = Confirmation/Expansion; 9.00-10.00 = High Level of Community Ownership.

The overall readiness score was $3.01 \pm 0.11$, which meant that the community was vague about concerns and did not contribute much more to motivate and mobilize decisionmaking. In six dimensions, the community climate and resources dominantly presented the higher scores, which were $4.01 \pm 0.16$ and $4.08 \pm 0.09$, respectively.

\subsubsection{Community Engagement}

Second, to investigate the community participation in biomass power generation projects, the respondents were asked their experiences at least once about joining the project in Southern Thailand, as presented in Figure 2. The most engaged were the informationgiving step $(75.38 \%)$ and passive participation $(20.1 \%)$, respectively. Respondents reported little engagement in consultation (3.02\%) and material incentives (1.51\%).

\section{Percentage of Community Involvement}

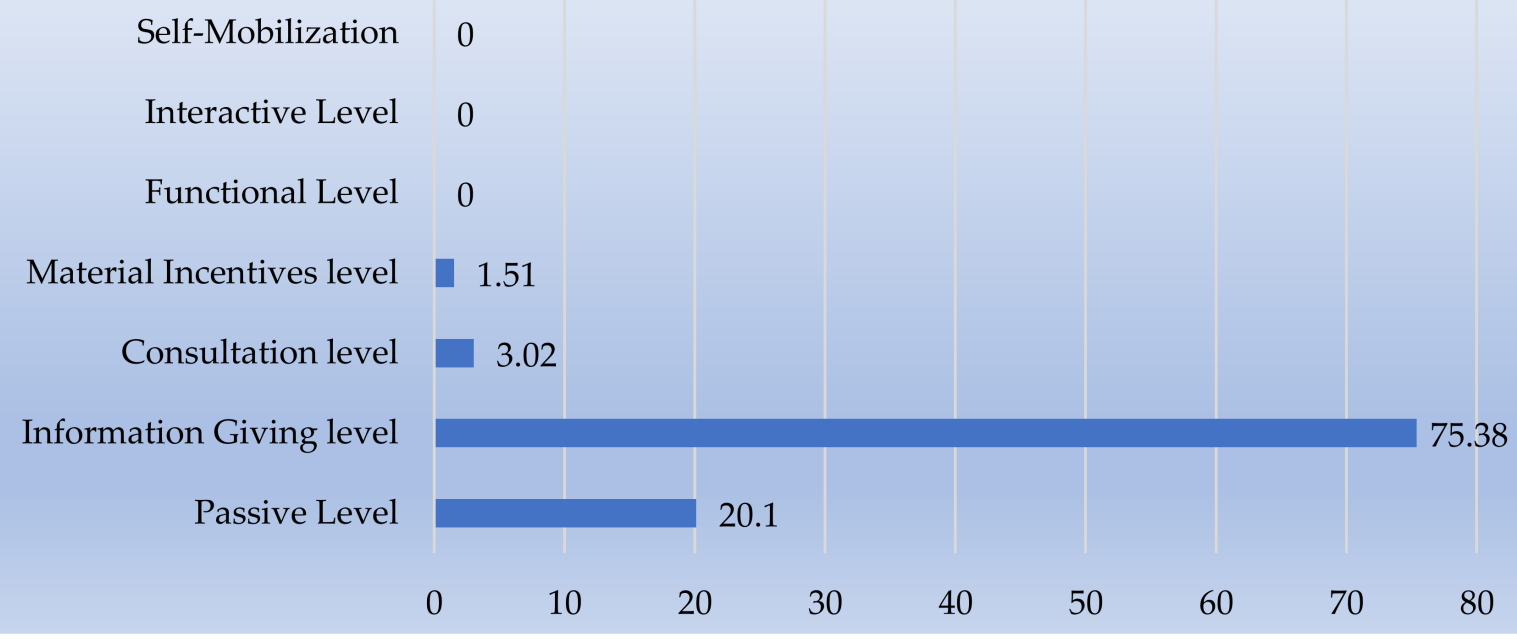

Figure 2. Percentage of respondents agreeing to the community participation experience $(\mathrm{N}=999)$.

\subsubsection{Pain Point Score}

Third, the pain points score analysis measured the specific problems experienced in the community using $0-10$ rating scale questionnaires. These scores were grouped into five levels: very mild, tolerable, very distressing, very intense, and excruciating unbearable. The average overall pain point score was $7.64 \pm 0.54$, which meant a highly intense level. The respondents most mentioned the pain points regarding environmental and health impacts 
as a result of the biomass power plants. The highest number of people also reported an excruciating unbearable level for respiratory problems $(9.99 \pm 1.01)$ and air pollution $(9.98 \pm 1.09)$ due to uncontrolled emissions. The first three rankings were 8.00-10.00, excruciating unbearable; $6.00-7.99$, very intense; $4.00-5.99$, very distressing, respectively. The respondents also reported other consequences of impacts in Table 3.

Table 3. Pain points score $(\mathrm{N}=999)$.

\begin{tabular}{|c|c|c|}
\hline Impact Consequences & Mean \pm S.D. & Pain Points Level \\
\hline Air pollutions /PM 2.5 & $9.98 \pm 1.09$ & excruciating unbearable \\
\hline Respiratory problems & $9.99 \pm 1.01$ & excruciating unbearable \\
\hline Skin irritation & $6.23 \pm 0.15$ & very intense \\
\hline Eye irritation & $8.45 \pm 0.49$ & excruciating unbearable \\
\hline Sound/noise disturbing & $6.62 \pm 0.08$ & very intense \\
\hline Odor/smell disturbing & $7.31 \pm 0.15$ & very intense \\
\hline Dust/Cleanliness & $7.35 \pm 0.34$ & very intense \\
\hline Water-soil source contamination & $9.01 \pm 1.02$ & excruciating unbearable \\
\hline Community conflicts & $8.99 \pm 1.02$ & excruciating unbearable \\
\hline Land use & $9.02 \pm 1.11$ & excruciating unbearable \\
\hline Crowded traffic/Road accident & $7.48 \pm 0.86$ & very intense \\
\hline Children safety & $8.85 \pm 0.86$ & excruciating unbearable \\
\hline Community discipline & $4.44 \pm 0.08$ & very distressing \\
\hline Unexpected criminal case & $7.22 \pm 0.57$ & very intense \\
\hline $\begin{array}{l}\text { Alcohol Tobacco and Drug } \\
\text { uncontrollable }\end{array}$ & $4.54 \pm 0.09$ & very distressing \\
\hline $\begin{array}{l}\text { Disease control and } \\
\text { public health problems }\end{array}$ & $8.84 \pm 0.57$ & excruciating unbearable \\
\hline Illegal immigration & $5.58 \pm 0.33$ & very distressing \\
\hline Overall Pain Point Scores & $7.64 \pm 0.54$ & very intense \\
\hline
\end{tabular}

Scores reported were on a scale of $0-10$, with 0 being the minimum and 10 being the maximum. Cut-off score: $0-1.99$ very mild; $2.00-3.99$ tolerable; $4.00-5.99$ very distressing; $6.00-7.99$ very intense; $8.00-10.00$ excruciating unbearable.

\subsection{Community Mobilization Using CHIA}

Improving community mobilization using CHIA was crucial in dealing with community readiness, engagement, and pain points. The study was embedded in community adherence to the biomass power plants in the panel discussions of the 153 participants presented in Table 4 . The participants were predominantly $66.67 \%$ male, and $54.25 \%$ were in the age range of 41-60 yrs. Considering the type of community role, comparatively more participants were $54.90 \%$ community members, $23.53 \%$ were health volunteers, and $77.12 \%$ had been living in the community for more than 20 years. 
Table 4. Study participants in panel discussion $(\mathrm{N}=153)$.

\begin{tabular}{|c|c|c|}
\hline Demographic Data & Number & Percentage \\
\hline \multicolumn{3}{|l|}{ Sex } \\
\hline Male & 102 & 66.67 \\
\hline Female & 51 & 33.33 \\
\hline \multicolumn{3}{|l|}{ Age range (years) } \\
\hline $20-40$ & 36 & 23.53 \\
\hline $41-60$ & 83 & 54.25 \\
\hline $61-80$ & 27 & 17.65 \\
\hline$>80$ & 7 & 4.58 \\
\hline \multicolumn{3}{|l|}{ Community Role } \\
\hline Leaders & 6 & 3.92 \\
\hline Health volunteers & 36 & 23.53 \\
\hline Government sector & 11 & 7.19 \\
\hline Civil society & 16 & 10.46 \\
\hline Community members & 84 & 54.90 \\
\hline \multicolumn{3}{|l|}{ Length of residence (years) } \\
\hline$<10$ & 8 & 5.23 \\
\hline 10-20 & 27 & 17.65 \\
\hline$>20$ & 118 & 77.12 \\
\hline
\end{tabular}

Community capacity building and mobilization using the CHIA process attempted to bring community participation before the biomass power plant investment and during its power generation, in order to achieve sustainable development and community 4.0 security in Southern Thailand. The following steps are plan, implementation, monitoring, and evaluation. The panel recommendations were then interpreted in terms of collective action and responsibility before the biomass power plant investment and power generation, as demonstrated in Table 5.

Table 5. Overview of convening presentations and panel discussions for community capacity building using the CHIA process $(\mathrm{N}=153)$.

\begin{tabular}{clll}
\hline \multirow{2}{*}{$\begin{array}{c}\text { Community } \\
\text { Mobilization Steps }\end{array}$} & \multicolumn{2}{c}{ Collective Action and Responsibility } \\
\cline { 2 - 4 } 1. Strategic management plan & Before Investment & During Power Generation \\
\hline First & $\bullet$ & $\begin{array}{l}\text { Conduct a community } \\
\text { need assessment and map } \\
\text { community priorities. }\end{array}$ & $\begin{array}{l}\text { Evaluate the community } \\
\text { mobilization effort using an } \\
\text { appropriate framework. }\end{array}$ \\
\hline Second & $\begin{array}{l}\text { Enhance cooperation } \\
\text { cross-sectoral partnership. }\end{array}$ & $\begin{array}{l}\text { Promote the exchange of } \\
\text { best practices among } \\
\text { communities. }\end{array}$ \\
\hline Third & $\begin{array}{l}\text { Stimulate people-centered } \\
\text { initiatives and approaches. }\end{array}$ & $\bullet$ & $\begin{array}{l}\text { Clarify the national and } \\
\text { regional levels } \\
\text { work together. }\end{array}$ \\
\hline
\end{tabular}


Table 5. Cont.

\begin{tabular}{|c|c|c|}
\hline \multirow{2}{*}{$\begin{array}{c}\text { Community } \\
\text { Mobilization Steps }\end{array}$} & \multicolumn{2}{|c|}{ Collective Action and Responsibility } \\
\hline & Before Investment & During Power Generation \\
\hline \multicolumn{3}{|l|}{ 2. Implementation } \\
\hline First & $\begin{array}{l}\text { Accelerate implementation } \\
\text { of the specific strategic } \\
\text { community plan. }\end{array}$ & $\begin{array}{l}\text { Raise awareness about the } \\
\text { impacts of biomass power } \\
\text { plants on community lives. }\end{array}$ \\
\hline Second & $\begin{array}{l}\text { Integration of community } \\
\text { development into energy } \\
\text { power agendas. }\end{array}$ & $\begin{array}{l}\text { - Investigate the impacts of } \\
\text { biomass power plants on } \\
\text { community lives } \\
\text { and benefits. }\end{array}$ \\
\hline Third & $\begin{array}{l}\text { Encourage public-private } \\
\text { partnerships and } \\
\text { community engagement. }\end{array}$ & $\begin{array}{l}\text { Dialogue the lesson learned } \\
\text { among the community and } \\
\text { public-private partnerships. }\end{array}$ \\
\hline \multicolumn{3}{|c|}{ 3. Monitoring and evaluation } \\
\hline First & $\begin{array}{l}\text { Address the community } \\
\text { climate crisis that } \\
\text { may occur. }\end{array}$ & $\begin{array}{l}\text { - Follow the policy and } \\
\text { regulatory frameworks. } \\
\text { Mitigation and } \\
\text { adaptation strategy. }\end{array}$ \\
\hline Second & $\begin{array}{l}\text { Monitor the right of } \\
\text { community participation in } \\
\text { decision-making processes. }\end{array}$ & $\begin{array}{l}\text { Reflect the political will and } \\
\text { societal awareness. }\end{array}$ \\
\hline Third & $\begin{array}{l}\text { - Critical appraisal of the } \\
\text { projects with transparency } \\
\text { and good governance. }\end{array}$ & $\begin{array}{l}\text { - Celebrate achievements/ } \\
\text { maintain renewable energy } \\
\text { for environmental protection } \\
\text { and sustainability, and } \\
\text { community resilience. }\end{array}$ \\
\hline
\end{tabular}

\section{Discussion}

This study attempted to present the common clues between environmental impact and social acceptance to sustainable biomass power plants [29], including the limitations and obstacles, similar to the others [30]. However, it is deeply intended to precisely describe the social aspects and is community-driven in order to live in harmony with the biomass power generation. Thailand's energy 4.0 has occupied a challenging platform with switching to low-carbon fuels in the power sector. Energy transition also has a crucial role in accelerating countries' decarbonizing climate ambitions and generating extra income for residents. The growth of biomass power plants is essential in expanding the country's economy, but those have long been controversial for their drawbacks [31], including Thailand.

For the first time, this study attempts to answer a detailed description of community approaches designed to empower the community capacity-building mobilization to-wards energy transitions in the era of Thailand 4.0. The findings revealed that community mobilization was significantly driven by the energy transition strategy, particularly biomass power plants in Southern Thailand. The key metrics that need to be measured before community mobilizations were community readiness, community participation, and community pain points related to biomass power plants.

First, to deal with energy conflicts between governmental actors and the community, the community readiness was considered a key element for engagement. Community readiness level was the first parameter to be involved in community resiliency by engaging 
in advocacy and collaboration with those decision-makers who compromised among all parties. Generally, the high community readiness scores significantly assist in predicting the success rate of community mobilization [32]. Although this study's overall score was only a vague awareness level, it eventually scaled up community resilience due to a strong community climate and resources. These two factors-the community climate reflected the prevailing attitude of the community, while resources were available to support their efforts to develop strategies.

Second, community engagement was an essential parameter to predict the good relationship between community and biomass power plants in the long run. Most respondents reported their opinions on the statements related to participation at a superficial level only in information-giving and passive participation in their community's biomass power plant initiatives. According to citizens, engagement played an important role in energy projects promotion [33]; the shallow participation level in this study reflected the low opportunity for the community to be consulted in the decision-making step. Since the energy transition needs to drive together with stakeholder engagement [34], the Thai royal government and local administrative organizations should support community-driven energy initiatives in Southern Thailand.

Third, those community's pain points also indicated a high level of dissatisfaction with biomass power plants that needed to pay attention to their concerns and solve the disturbances as fast as possible. This measuring of pain point severity was critical to biomass power plant improvement priorities, and to understanding the impact of promoting ecosystem and community-friendly projects. In general, the fewer pain point levels indicated, the lower problems related to the community bio-mass projects. However, no items were recognized as the lower score, such as 0-1.99 (very mild) and 2.00-3.99 (tolerable). In contrast, the first three levels were presented as 8.00-10.00 (excruciating unbearable), 6.00-7.99 (very intense), and 4.00-5.99 (very distressing), respectively. Since these pain points were both current and expected problems-unintended consequences that occurred at the different levels of the respondent's experiences in their community biomass power plants-these problems needed to be considered and all negative impacts on community living attempted to be lowered. Thus, the progress of energy transition requires more sustainable solutions, particularly regarding pleasant and desirable community attitudes towards biomass power plants.

Fourth, the application of the CHIA — the democratize empowered community approachplayed a crucial role in community mobilization through facilitated participatory learning, particularly in rural settings, to identify their own needs due to biomass power plant projects to improve environmental and health outcomes. Based on the community investigation mentioned above, the proposed process was the strategic management plan, implementation, monitoring, and evaluation to regulate the community-driven development of the biomass power plants in their community.

Finally, all processes were well-designed for the community which lacks scientific knowledge, low readiness, and partial engagement to biomass power plants, providing system encouragement for ecological and socioeconomically value based on dwelling environment, health, and well-being in rural Southern Thailand. In other words, community readiness, engagement, and pain point scores were evidence for the decision-makers to propose a community framework, public policy, and capacity building for the community. The CHIA worked as a part of building blocks' framework [35] with a democratizing process to support the local community and population health through learning using community-based data-sharing, developing stakeholder agreements, and decision-making as partnerships in the context of determinants of health [36] to achieve health equity and a sustainable environment.

\section{Conclusions}

For the first time, this study highlighted the novelty insight of community capacitybuilding mobilization towards energy transitions in the era of Thailand 4.0, a case study on 
biomass power plants in Southern Thailand. First, CRM played a critical role influencing the provision of the baseline data for community readiness, involvement, and their pain points. Second, the CHIA process presents a crucial role based on community baseline data to build the collaborative mobilization plan, implementation, monitoring, and evaluation to achieve the public policy towards biomass power plants in Southern Thailand. The new directions of future scientific studies in monitoring and evaluating energy transition status in Thailand should simultaneously involve community learning tools, such as CHIA, to detect and probe the impact timeframes for renewable energy by the community themselves. The findings suggested that the policy recommendation should address social determinants of health, engage stakeholders, and build community efforts in social and scientific platforms to ensure community ownership, value addition, public acceptance, and maintenance sustainability.

Author Contributions: Y.H.-collected the data; P.S.- - conceived and designed analysis; and S.N. conceived and designed analysis, collected the data, contributed data or analysis tools, performed the analysis, and wrote the paper. All authors have read and agreed to the published version of the manuscript.

Funding: This research was funded by the National Research Council of Thailand (NRCT) on the research title "Community Readiness on Adopting Community Health Impact Assessment for Building Health Public Policy: A Case Study of Community Operating for Biomass Power Plant Construction in Southern Thailand". The grant number was 39/2560 (May 2017, 09).

Institutional Review Board Statement: The study was conducted according to the guidelines of the Declaration of Helsinki, and approved by the Institutional Review Board, Public Policy Institute, Prince of Songkla University, Thailand (Reference number 19/2559).

Informed Consent Statement: Informed consent was obtained from all subjects involved in the study.

Data Availability Statement: Not Applicable.

Acknowledgments: The authors would like to acknowledge the Health Impact Assessment Research Center (HIA-RC, PSU), Public Policy Institute, Prince of Songkla University, Thailand, for the publication support. We also appreciate all the participants who gave up their valuable time to take part in this study.

Conflicts of Interest: The authors declare no conflict of interest.

\section{References}

1. Sriboonlue, P. Strategic Entrepreneurial Awareness and Business Performance: Empirical Evidence from Small and Medium-sized Enterprises in Thailand. In Proceedings of the 3rd World Conference on Technology, Innovation and Entrepreneurship, "Industry 4.0 Focused Innovation, Technology, Entrepreneurship and Manufacture", Istanbul, Turkey, 21-23 June 2019; Volume 158, pp. 653-661. [CrossRef]

2. Chancharoonpong, P.; Mungkung, R.; Gheewala, S.H. Life Cycle Assessment and eco-efficiency of high value-added riceberry rice products to support Thailand 4.0 policy decisions. J. Clean. Prod. 2021, 292, 126061. [CrossRef]

3. Lakha, F.; Suriyawongpaisul, P.; Sangrajrang, S.; Leerapan, B.; Coker, R. Breast cancer in Thailand: Policy and health system challenges to universal healthcare. Health Policy Plan. 2020, 35, 1159-1167. [CrossRef] [PubMed]

4. Bissen, R.; Chawchai, S. Microplastics on beaches along the eastern Gulf of Thailand-A preliminary study. Mar. Pollut. Bull. 2020, 157, 111345. [CrossRef]

5. Ghazouani, T.; Boukhatem, J.; Sam, C.Y. Causal interactions between trade openness, renewable electricity consumption, and economic growth in Asia-Pacific countries: Fresh evidence from a bootstrap ARDL approach. Renew. Sustain. Energy Rev. 2020, 133, 110094. [CrossRef]

6. Misila, P.; Winyuchakrit, P.; Limmeechokchai, B. Thailand's long-term GHG emission reduction in 2050: The achievement of renewable energy and energy efficiency beyond the NDC. Heliyon 2020, 6, e05720. [CrossRef] [PubMed]

7. Sereenonchai, S.; Arunrat, N.; Stewart, T.N. Low-carbon city communication: Integrated strategies for urban and rural municipalities in Thailand. Chin. J. Popul. Resour. Environ. 2020, 18, 16-25. [CrossRef]

8. Kusumadewi, T.V.; Winyuchakrit, P.; Limmeechokchai, B. Long-term CO2 Emission Reduction from Renewable Energy in Power Sector: The case of Thailand in 2050. Energy Procedia 2017, 138, 961-966. [CrossRef]

9. Khaenson, W.; Maneewan, S.; Punlek, C. Assessment of the environmental impact of biomass electricity generation in Thailand. Int. J. Renew. Energy Res. 2018, 8, 302-312. 
10. Aberilla, J.M.; Schmid, A.G.; Azapagic, A. Environmental sustainability of small-scale biomass power technologies for agricultural communities in developing countries. Renew. Energy 2019, 141, 493-506. [CrossRef]

11. Ahmed, O.; Ries, M.J.; Northrop, W.F. Emissions factors from distributed, small-scale biomass gasification power generation: Comparison to open burning and large-scale biomass power generation. Atmos. Environ. 2019, 200, 221-227. [CrossRef]

12. Lin, S.; Tian, H.; Hao, Y.; Wu, B.; Liu, S.; Luo, L.; Bai, X.; Liu, W.; Zhao, S.; Hao, J.; et al. Atmospheric emission inventory of hazardous air pollutants from biomass direct-fired power plants in China: Historical trends, spatial variation characteristics, and future perspectives. Sci. Total. Environ. 2021, 767, 144636. [CrossRef] [PubMed]

13. Elisa, P.; Alessandro, P.; Andrea, A.; Silvia, B.; Mathis, P.; Dominik, P.; Manuela, R.; Francesca, T.; Voglar, G.E.; Tine, G.; et al. Environmental and climate change impacts of eighteen biomass-based plants in the alpine region: A comparative analysis. $J$. Clean. Prod. 2020, 242, 118449. [CrossRef]

14. Paletto, A.; Bernardi, S.; Pieratti, E.; Teston, F.; Romagnoli, M. Assessment of environmental impact of biomass power plants to increase the social acceptance of renewable energy technologies. Heliyon 2019, 5, e02070. [CrossRef] [PubMed]

15. Famoso, F.; Prestipino, M.; Brusca, S.; Galvagno, A. Designing sustainable bioenergy from residual biomass: Site allocation criteria and energy/exergy performance indicators. Appl. Energy 2020, 274, 115315. [CrossRef]

16. Prestipino, M.; Salmeri, F.; Cucinotta, F.; Galvagno, A. Thermodynamic and environmental sustainability analysis of electricity production from an integrated cogeneration system based on residual biomass: A life cycle approach. Appl. Energy 2021, 295, 117054. [CrossRef]

17. Waewsak, J.; Ali, S.; Gagnon, Y. Site suitability assessment of para rubberwood-based power plant in the southernmost provinces of Thailand based on a multi-criteria decision-making analysis. Biomass Bioenergy 2020, 137, 105545. [CrossRef]

18. Stephanides, P.; Chalvatzis, K.J.; Li, X.; Mantzaris, N.; Prodromou, M.; Papapostolou, C.; Zafirakis, D. Public perception of sustainable energy innovation: A case study from Tilos, Greece. Energy Procedia 2019, 159, 249-254. [CrossRef]

19. Liu, L.; Bouman, T.; Perlaviciute, G.; Steg, L. Public participation in decision making, perceived procedural fairness and public acceptability of renewable energy projects. Energy Clim. Chang. 2020, 1, 100013. [CrossRef]

20. Aunphattanasilp, C. Civil society coalitions, power relations, and socio-political ideas: Discourse creation and redesigning energy policies and actor networks in Thailand. Energy Res. Soc. Sci. 2019, 58, 101271. [CrossRef]

21. Nuntaboot, K.; Boonsawasdgulchai, P.; Bubpa, N. Roles of mutual help of local community networks in community health activities: Improvement for the quality of life of older people in Thailand. Int. J. Nurs. Sci. 2019, 6, 266-271. [CrossRef]

22. Galai, N.; Sirirojn, B.; Aramrattana, A.; Srichan, K.; Thomson, N.; Golozar, A.; Flores, J.M.; Willard, N.; Ellen, J.M.; Sherman, S.G.; et al. A cluster randomized trial of community mobilization to reduce methamphetamine use and HIV risk among youth in Thailand: Design, implementation and results. Soc. Sci. Med. 2018, 211, 216-223. [CrossRef] [PubMed]

23. Chaiyapa, W.; Hartley, K.; Alvarez, D.D.B. From end-users to policy designers: Breaking open the black box of energy technocracy in Thailand. Energy Res. Soc. Sci. 2021, 73, 101912. [CrossRef]

24. Anderson-Carpenter, K.D.; Watson-Thompson, J.; Jones, M.D.; Chaney, L. Improving Community Readiness for Change through Coalition Capacity Building: Evidence from a Multi-Site Intervention. J. Community Psychol. 2017, 45, 486-499. [CrossRef] [PubMed]

25. Harris, K.J.; Brown, B.; Shankle, L.; Tryon, M.; Pedersen, M.; Panarella, S.K.; Swaney, G. Community Readiness Model for Prevention Planning: Addressing Childhood Obesity in American Indian Reservation Communities. J. Racial Ethn. Heal. Disparities 2019, 6, 1144-1156. [CrossRef]

26. Nwagu, E.N.; Dibia, S.I.C.; Odo, A.N. Community Readiness for Drug Abuse Prevention in Two Rural Communities in Enugu State, Nigeria. SAGE Open Nurs. 2020, 6, 2377960820963758. [CrossRef] [PubMed]

27. Jabot, F.; Tremblay, E.; Rivadeneyra, A.; Diallo, T.A.; Lapointe, G. A Comparative Analysis of Health Impact Assessment Implementation Models in the Regions of Montérégie (Québec, Canada) and Nouvelle-Aquitaine (France). Int. J. Environ. Res. Public Health 2020, 17, 6558. [CrossRef]

28. Rogerson, B.; Lindberg, R.; Baum, F.; Dora, C.; Haigh, F.; Simoncelli, A.; Williams, L.P.; Peralta, G.; Porter, K.P.; Solar, O. Recent Advances in Health Impact Assessment and Health in All Policies Implementation: Lessons from an International Convening in Barcelona. Int. J. Environ. Res. Public Heal. 2020, 17, 7714. [CrossRef]

29. Kashif, M.; Awan, M.; Nawaz, S.; Amjad, M.; Talib, B.; Farooq, M.; Nizami, A.; Rehan, M. Untapped renewable energy potential of crop residues in Pakistan: Challenges and future directions. J. Environ. Manag. 2020, 256, 109924. [CrossRef]

30. Cuong, T.T.; Le, H.A.; Khai, N.M.; Hung, P.A.; Linh, L.T.; Thanh, N.V.; Tri, N.D.; Huan, N.X. Renewable energy from biomass surplus resource: Potential of power generation from rice straw in Vietnam. Sci. Rep. 2021, 11, 1-10. [CrossRef]

31. Baasch, S. Energy transition with biomass residues and waste: Regional-scale potential and conflicts. A case study from North Hesse, Germany. J. Environ. Policy Plan. 2021, 23, 243-255. [CrossRef]

32. Abi, M.; Kessler, A.; Oosterveer, P.; Tolossa, D. Adapting the current mass mobilization approach in Ethiopia to enhance its impact on sustainable land management: Lessons from the Sago-kara watershed. J. Environ. Manag. 2019, 248, 109336. [CrossRef] [PubMed]

33. De Crescenzo, V.; Baratta, R.; Simeoni, F. Citizens' engagement in funding renewable and energy efficiency projects: A fuzzy set analysis. J. Clean. Prod. 2020, 277, 124060. [CrossRef] 
34. van Summeren, L.F.; Wieczorek, A.J.; Bombaerts, G.J.; Verbong, G.P. Community energy meets smart grids: Reviewing goals, structure, and roles in Virtual Power Plants in Ireland, Belgium and the Netherlands. Energy Res. Soc. Sci. 2020, $63,101415$. [CrossRef]

35. Sacks, E.; Morrow, M.; Story, W.T.; Shelley, K.D.; Shanklin, D.; Rahimtoola, M.; Rosales, A.; Ibe, O.; Sarriot, E. Beyond the building blocks: Integrating community roles into health systems frameworks to achieve health for all. BMJ Glob. Heal. 2019, 3 , e001384. [CrossRef] [PubMed]

36. Boulware, L.E.; Harris, G.B.; Harewood, P.; Johnson, F.F.; Maxson, P.; Bhavsar, N.; Blackwelder, S.S.; Poley, S.S.; Arnold, K.; Akindele, B.; et al. Democratizing health system data to impact social and environmental health contexts: A novel collaborative community data-sharing model. J. Public Health 2020, 42, 784-792. [CrossRef] [PubMed] 